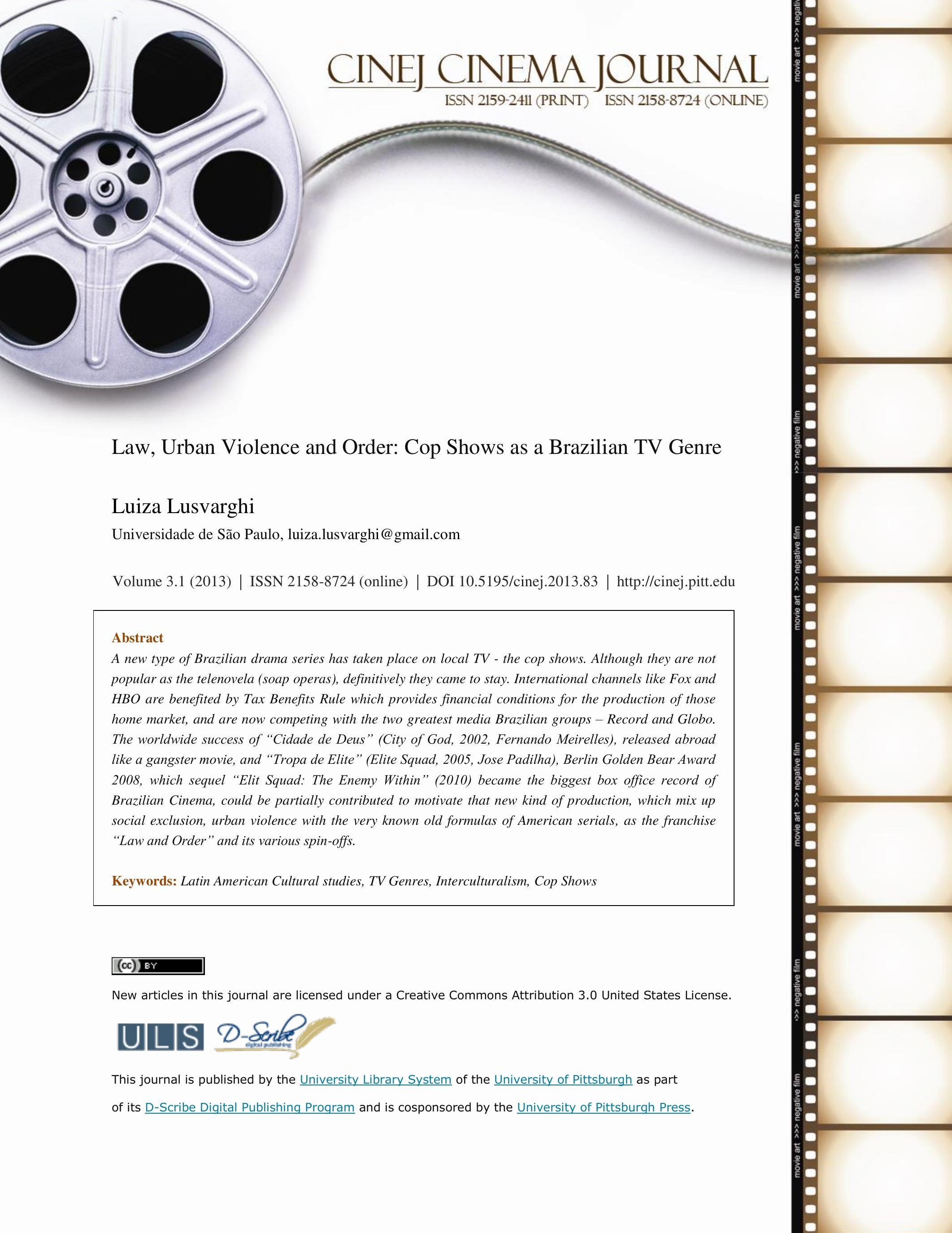




\section{Law, Urban Violence and Order: Cop Shows as a Brazilian TV Genre}

\section{Luiza Lusvarghi}

Urban violence and police series seem to be the order of the day in Brazil, or, at least, an alternative investment strategy. Since 2009, while Fox Channel launched its Brazilian police series, the franchise 9 MM: São Paulo (2008-2011), Record Entretenimento announced plans to transform its mini-series "A Lei e o Crime" (Law and Crime, 2009) into a film, and Globo announced the third season of "Força-Tarefa" (Task Force, 2009-2011), a series about a special Police command unit, aimed at combating corruption within the corporation in Rio de Janeiro, cop shows are in evidence.

The pioneer was HBO, with the series "Mandrake", released in 2005, with a leading character based on the novels written by Rubem Fonseca, and later adapted into a telefilm in 2012. After the end of 9 MM São Paulo, Fox aired "Contos do Edgar" (Edgar Tales,

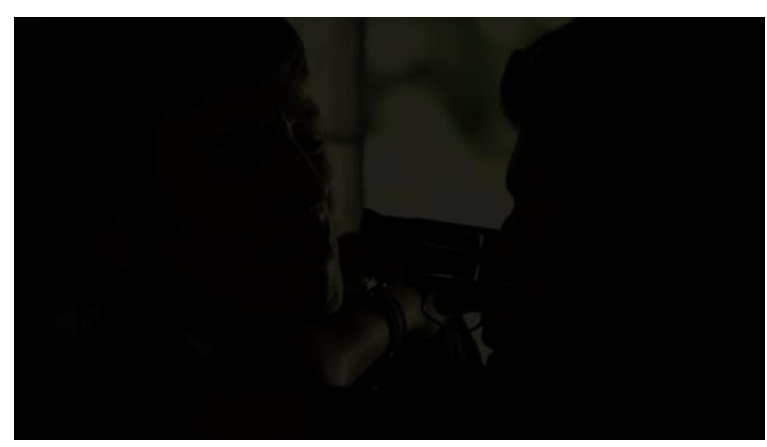
2013), inspired by Edgar Allan Poe's novels and produced by Fernando Meirelles. Record Entretenimento, owned by the Pentecostal church Universal do Reino de Deus, is also planning a new cop series in partnership with Fox Film. The latest Record cop show series was "Fora de Controle" (Out of Control, image on the left), aired in 2012, and since then, they seemed to be much more interested in the 
production of mini-series about Christianism and the versions of the Bible. Globo Network, the greatest Brazilian Media Group, announced the release of two cop series in 2014, “A Teia” (The Web), based on a real story, and "O Caçador" (The Hunter).

However, low-paid and far from heroism, the Brazilian cops live in a state of permanent conflict between the criminal justice system and the corruption of the corporation.

The idea of this article, based on a research about new Brazilian formats and genres, is to try and understand how this production keep the tradition of TV genre and at the same time create new local forms taking concepts proposed by Jason Mittell (2004) as starting points, looking at the issue of genre on television not as something intrinsic to the text or cinema, but rather as a cultural category (Mittell, 2004), as to him the category concept considers both cultural practices and audiences practices within a cultural context. Nestor Canclini's definition of hybrid cultures is also relevant to this analysis, as he sees the importance of the production of intercultural works in current times, a concept he establishes as being in conflict with the transnational term that would represent the predominance of the monopoly of large international media groups over local and regional production. He argues that "the question on how to create a cultural cinema and television must be understood as a quest on how to deal with interculturalism" (Garcia Canclini, 2008).

In order to understand the relation between contemporary Brazilian police series and local traditions within a specifically national cultural context, and also its relation with foreign counterparts, it is fundamental to approach the appearance of crime films within national cinema, as Brazilian literature, contrary to European and North American, did not 
generate works based on the police genre, and even less so authors such as Dashiel Hammet, Agatha Christie or even George Simenon. Brazilian suspense literature and detective stories are a far more recent phenomenon. This trend can be identified in certain works produced from the start of the 1990s, and is situated between parody, through references to HQ, such as the detective Ed Mort, by Luis Fernando Veríssimo i, which was eventually turned into a film, and the urban police fiction of Luiz Alfredo Garcia-Roza and his detective Espinoza, a typical inhabitant of Rio's Copacabana neighborhood.

At the outset of national cinema, police chronicles and political satire were always sources of inspiration. Police chronicles boosted the first successful Brazilian productions, and film titles practically summarized the police chronicle of that time. It is thought that the first fiction film appeared in 1908, "Os Estranguladores" (The Stranglers) or "Fé em Deus", based on a real crime that took place in Rio. Two teenagers were strangled by a gang lead by Gerônimo Pegatto, owner of the boat "Fé em Deus" (Keep on Faith). The story was initially staged in theater. The young teacher from São Paulo that knifed her groom on Carnival Tuesday resulted in "Tragédia Paulista" (Tragedy in São Paulo), also released under the title "Noivado de Sangue" (Bloody Wedding, 1908), the story of strangler Miguel Trad who quartered his victim and placed the parts in a suitcase gave rise to "O Crime da Mala" (Suitcase Crime) during the same period" (Salles Gomes, 1980, p. 32).

At a time when there was no television, the idea of exploring crime through cinema was presented with endless opportunities. In 1913, three films revolved around this topic: "O Caso dos Caixotes", based on a robbery, "O Crime de Paulo Matos" (Paulo Matos`s 
Crime), based on the murder of industrialist Adolfo Freire, and "O Crime dos Banhados" (Banhados's Crime), a feature film about the massacre of a family that ran for almost two hours!

The soundtracks of foreign productions were recorded, but Brazilian films were sang and played live. The high points of the sung and spoken genre were the slapstick comedies that parodied the government, placing stars from the local variety theater on stage. But crimes always had a guaranteed spot in the heart of the public. These productions were extremely simple, quickly put together so as to be released before the subject was forgotten.

The success of films based on crimes is understandable, because in a manner of speaking the national product at that time fulfilled the role that is currently filled by television documentaries and today's sensationalist news. On the other hand, it was a way for national producers to compete with refined foreign productions without having to spend too much.

Throughout a number of periods, films based on police chronicles competed to attract more public to Brazilian cinema. Possibly due to the absence of a literary tradition within this specific genre among us, and the establishment of foreign, and, above all, American production of the genre in cinema, and later, in the 1950s, on television, this type of narrative never achieved a public as loyal as those of the chanchadas ${ }^{\mathrm{iii}}$ or political satire and comedies in Brazil.

The relation between crime films and television series is historic and not limited to the Brazilian example. After all, as said by Orson Welles, "television is the enemy of classical cinematographic values, but not of cinema" (Welles apud Neale 2002). The word genre comes from the French language and means "type" or kind. The categories in which 
film genres are divided have always been the object of discussion throughout the history of cinema, and were greatly influenced by the consolidation and expansion of the American film industry in global terms. The western, gangster films, musicals, melodramas, horror films, all appear as a result of this consolidation (Neale, 2002). Occasionally, the term subgenre is also used to refer to a combination derived from those principle genres, such as, for example, romantic comedies, gothic horror films, etc. Another widely used term is 'cycle' to refer to a group of films guided by a certain aesthetic, stylistic trend, during a certain period, such as, for example, the cycle of historical adventure films: “Treasure Island", “The Count of Monte Cristo", from 1934.

In the 1960s and 1970s it was quite common to associate film genres with those of genre theories in literature, especially so because literary genre and adaptations of famous literary pieces would take cinema out of the limbo of popular culture without artistic importance (Stam, 2003). However, while the existence of a literary theory is accepted as knowledge, it is ignored in practice. One of the reasons, according to Steve Neale, could be the apparent discrepancy between the generic terms and divisions in literature and the terms and divisions familiar to critics and theorists in cinema. In literature we have novella, drama, poetry, but it is difficult to adapt these categories directly for cinema. Furthermore, these categories have been through historical transformations. The word genre in cinema can often be replaced by film narrative, which according to the author is the true genre. The predominant image representing the critique of genre is a triangle composed of the artist/film/audience (Neale, 2004). Genre can be defined as models/forms/styles/structures that "transcend individual films, and that guide both their construction by the filmmaker and their reception by the audience". 
The global development and expansion of the American film industry was the main factor that helped consolidate a genre policy for cinema. This means that the commercially predominant genres impose themselves on others. But, even though certain classifications are always more easily accepted, they diverge from one time to another, and one country to another, as pointed out by Robert Stam. Melodrama doesn't have the same connotation in Brazil and India. And why should we ignore terms such as samurai films and kung fu films often mistaken by martial arts films - genres?

The classification of the genre in cinema is largely influenced by the ideal classification for the sales shelves, as such categorization is chiefly aimed, in the case of cinema, at the market rather than accurately representing the content of the film. This was previously brought to our attention by Adorno in his famous text "Dialectic of Enlightenment" about the issues of A and B films, defined in terms of consumption potential, and from internal demands, and not necessarily in terms of artistic quality.

In the recent past, so-called B movies, for example, included police film noir, and as is commonly known, within post-modernity, there is a certain renewal of the kitsch aesthetic, of police noir films and even of the classic horror and gothic, not necessarily applied to works of lesser artistic value.

Genre on television - the classification of fiction series genres on television are rooted in cinema and radio. B movies from Universal drew material for American series, the so-called canned laughter, like "Batman and Robin". Film noir, also considered B productions, came from American literature to influence part of the police films and detective series. 
Brazilian Sitcoms are influenced by American TV, as was the case among us with "Família Trapo" (Trapo Family), from Record, and "A Grande Família" (The Big Family), created by Vianinha, on Globo.

The category used by Neale to specify detective, gangster and suspense thriller films is Contemporary Crime. The oldest American detective films include "The Adventures of Sherlock Holmes" (1905), "A Career of Crime" (1900). Discussions on detective films has been dominated by the issue of film noir, used to refer to films from a certain period and linked to police literature, such as The Maltese Falcon (1941), based on the book by Dash Hammet. As a result, films that don't fit within this stylistic trend are ignored, which, according to Neale, would be a problem. However, the category film noir is largely associated to authorism, and in a certain manner confers a cult-like air to less banal films that could be classed in another genre. Clearly, comedy and melodrama are words easily identifiable by consumers and filmmakers, but film noir is certainly an expression created by critique, Stam warns. In the 1940s, film noir filmmakers did not create films based on this concept. "Body Heat" (1981), by Lawrence Kasdan, and more recently "The Black Dahlia" (2006, USA, Germany), are far more conceptual and conscious.

Gangster films occupy a privileged position in the genre theory. As with westerns, it was a reference for studies in the 1960s and 1970s. A good part of this favor is due to the essay "The Gangster as Tragic Hero", by Robert Warshow, considered by many just another essay about culture, rather than film theory. Whatever the case, it could also be very reductive. Fernando Meirelles' "Cidade de Deus" (City of God), was released as a film about gangs and a gangster film, which earned it an association with the work of 
Martin Scorsese, but reduced the possibility for debates surrounding the film itself (SHAW in Vieira, 2005, pg 58).

Police genre on current American television will present very specific breakdowns, constituted as currently one of the most profitable niches to be explored notably by American franchises SCI and Law \& Order. But one of the greatest hits in that genre on American TV was the series "Dragnet", which was based on a radio show, released in 1949.

In Brazil, police and suspense films do not have the same historic tradition as the United States. In 1954, the first action series produced in Brazil, "Capitão 7", was aired. At that time, series that sought to imitate the American format of fiction series were produced at the same time as those similar to soap operas, originally from tele-theaters - theatrical performances broadcast live - and from radio. These performances would include adaptations of mystery tales and novellas (TV Mistério), not necessarily police stories, both on TV Tupi (in the Southeast) and TV Ceará (in the Northeast).

Soap operas and tele-theater were initially broadcast live, as video tape would only be introduced in the 1960 s, and the subject matter was almost entirely romantic. The NorthAmerican agencies McCann Erikson and W. J.Thompson dominated the production of television programs, as the domestic market did not include specialized professionals, and imposed their adverts and products.

The first daily soap opera, however, was "2-549984 Ocupado" (2-549984 Occupied), produced by TV Excelsior. As emphasized by the broadcaster's artistic director of that period, Álvaro de Moya ${ }^{\text {iv }}$, in spite of the theatrical origin of the texts and adaptations, which conferred theater actors a status superior to their colleagues from radio, 
mastery of film language was an exceptionally desirable criterion for an actor wanting a good role on the small screen.

However, the group who would establish the genre of telenovela in Brazil would be Rede Globo, with a telenovela called "Irmãos Coragem" (Courage Brothers), in the 1970s. Portraying the urban sophistication of Rio de Janeiro and, less often, São Paulo, and the rest of Brazil as the backward country was common in the plots of Globo's telenovelas over three decades.

On certain occasions though, Globo invested in police series. In 1979, they launched an effort with "Plantão de Policia" (Cops on Duty), created by Bráulio Pedroso, Aguinaldo Silva, Doc Comparato, experienced authors of Brazilian television. The series was about the adventures of a veteran journalist, Waldomiro Pena (Hugo Carvana), who was given the job of covering police cases for his newspaper.

In 1997, Globo star Malu Mader gave life to the character of police officer Diana Maciek in 12 episodes of the series "A Justiceira" (The Protectors), a new attempt by the broadcaster to create an action series with all the clichés of American police dramas. At that time, the series, directed by Daniel Filho and José Alvarenga Jr., who currently directs "Força-Tarefa" (Task-Force), was filmed entirely on $35 \mathrm{~mm}$ film. "A Justiceira" managed to prove that a Brazilian production could display the same technical efficiency as the foreign genre - it was, however, unsuccessful in its attempt.

Since the announcement of Rio as the official host of the 2016 Olympic Games, and the creation of the Rio Film Commission, chaired by Steve Solot, a former MPA representative in Brazil, with the intention of transforming the city into a prime location for foreign productions with the support of incentive laws and investments, speculations 
surrounding productions have been rife, and even involve well known names such as Woody Allen. The movies "Fast Five" (also known as Fast \& Furious 5: Rio Heist, 2011) and "The Expendables" (USA, 2010), directed by Silvester Stallone, were two of these productions. The success of films such as "Cidade de Deus" and "Tropa de Elite" has certainly contributed to the establishment of a new type of approach to national reality, far from the model made famous through Cinema Novo, with a fast paced narrative classified by many critics as a music video jump cut, the MTV aesthetics at the movies.

Previous attempts, actually, always avoided placing police officers as leading characters in series and telenovelas. Agents and investigators were always relegated to furtive cameos in telenovelas and series. The lack of interest cannot hide the problem of illegitimacy of the police in the Brazilian public consciousness. Commonly associated to dictatorships, from Vargas to the military coup of 64 , the Brazilian police - poorly paid, an instrument of political repression in the past, and currently almost always accused of corruption and alliances with the underworld -, have always been a target of mistrust by the population. With this bad reputation, it is difficult to cast them as heroes or good guys in fictional narratives. Thus the extreme success of American series.

The police genre is definitively gaining a Brazilian identity and begins to invade television screens. After the talk of the frustrated efforts to transform "Tropa de Elite" the film gained an international version and a Silver Bear in Berlin in 2009 -, into a series, Globo launched its first investigative series portraying the daily life of a group of police officers investigating the actual police. "Força-Tarefa", written by Fernando Bonassi from "Carandiru" (2003), the story about the famous Brazilian penitenciary where police force killed 111 men - and Marçal Aquino - screenwriter of "O Invasor" (Beto Brant, The 
Trespasser, 2009) - shows seven officers that form a unit aimed at investigating conduct deviances of other members of the corporation. The director is José Alvarenga Jr. In the series, a unit is led by Coronel Caetano, played by Milton Gonçalves, but the action of the story surrounds Lt. Wilson, played by Murilo Benício. Pernambuco actress Hermila Guedes plays Selma, the lieutenant's right hand. In addition to these three, the team includes Jorge (Rodrigo Einsfeld), Irineu (Juliano Cazarre), Oberdan (Henrique Neves) and Genival (Osvaldo Barauna). Selma, being the only women in the corporation, provides an androgynous sexual image.

The appearance of TV dramas with a more defined profile in terms of format and theme such as "A Lei e o Crime" (Law and Crime), on Record, "Força-Tarefa" (Task Force), on Globo, "9 MM", from Fox and "Mandrake", from HBO, fosters thoughts regarding a new trend within fiction series in Brazil, very different to telenovelas and miniseries, which blend American police film language with a naturalist aesthetic that makes use of all resources to speak of violence and poverty. If on one hand the approach follows a line very different to that legitimized by the works of Cinema Novo, above all in those productions that were likened to Italian Realism, such as "Rio 40 Graus" (Rio 40

Degrees, 1955), on the other hand some of them are related to the works that became famous in the international market, such as "Os Cafajestes" (The Unscrupulous Ones, 1962), by Ruy Guerra, and which were never as popular in Brazil. Different to their counterparts, Brazilian policemen are not modeled on unflagging heroism, as suggested in the series of the American genre, such as Law and Order, CSI and Cold Case. They are people of flesh and bone, with problems at home, some involving corruption, and, above all, how police officers live in a country with serious 
conflicts of social order and development, with very little money left to spare. No large cars, or luxury apartments, nor any sophisticated investigative technology.

Even with a more sophisticated framework, this humanization of the role of the police officer can also be found in the Argentinean series "Epitafios", another HBO partnership aimed at the Latino market, and shown in Brazil in 2009 in its second season, with the lead character played by Cecília Roth. The second season of "Epitáfios"TM" (Epitaphs), the anticipated co-production between HBO Latin America and Argentinean producer Pol-ka, took a long time to be released. The first season was broadcast in 2004, and was sorely missed - those wanting to watch the series again will have to rely on You Tube, as it was only sold on DVD in the USA. The detective team Renzo Márquez (Julio Chávez) and Marina Segal (Cecília Roth, Almodóvar’s Sexília) unite once again to face a serial killer that, apparently, reproduces crimes that had already been committed using photographic reconstructions of records released to the press. Up to that particular point it deserves little special attention, except for the environment of the station, which is certainly far more reminiscent of Brazilians and Latinos than Americans.

In the Record series, "A Lei e o Crime" (Law and Crime), the drug dealer is the good guy, who gets involved with crime to get revenge on his brother-in-law, a corrupt cop. In fact, the police officers in the series are not models of good behavior, and salvation from corruption come in the figure of a Police Chief new to the business - from a rich and influential family, she decides to become a police officer after witnessing her father being killed by criminals. "A Lei e o Crime" was screened by Rede Record between January 5 and June 8, 2009, led by Ângelo Paes Leme, playing the role of Nando da Bazuca, and Francisca Queiroz, in the role of Chief Catarina. It tells the story of Nando (Ângelo Paes 
Leme), an ex-paratrooper in his 30s that kills his father-in-law and is being hunted by his brother-in-law, police officer Romero (Caio Junqueira). At the same time, there is the story of Catarina (Francisca Queiroz), a woman from the upper class, who decides to become a police Chief after her father is murdered. The Record police series resulted in a number two rank in Ibope (Brazilian Institute of Public Opinion and Statistics, a private agency).

The fight between Record and Globo, the two largest Brazilian holdings, is expected to intensify. In the case of the first two the fight is for achieving a monopoly of the Brazilian market. Telenovelas and now television films, which will enjoy support from tax waiver laws, are part of this dispute. Rumors that both will be disputing the primacy of transforming "Elit Squad" in a series filled specialized columns, never confirmed, as so that the director José Padilha would prefer to invest in a third film of the series. But, what about Fox and HBO? Naturally, the Latino productions of both, and, above all, the Brazilians, took advantage of tax waiver laws that guarantee support for local production of foreign channels (Condecine). This stimulus, however, is not sufficient to justify these productions.

The segmentation of markets and the expansion of media conglomerates, via franchising and the Internet, require transnational products that sustain the empire of large brands. Thus, investing in local and regional productions, in both cinema and television, may be a far more political than economical strategy of defining boundaries and perfecting competitively. If, on one hand, the expressive expansion strategy model via 'think globally, act locally' strengthens the cultural entertainment industry - based on the model of American society -, on the other hand, it instigates contradictions between models of development and cultural standards, nevertheless giving rise to films and alternative modes 
of production, almost like a reforestation of the audiovisual industry, in diverse parts of the world.

In certain cases, these new productions are responsible for placing new characters in the spotlight, those socially excluded from the society of global consumption. Canclini (2006) raises awareness about the need to discuss the role of the work within the audiovisual industry so as to better understand how these new genres appear and which role they play. It doesn't make much sense to discuss films and television series as though they are merely artistic products. And dealing with this new reality certainly implies understanding the universe of co-productions and their partnerships (Mercosur, Ibermedia), so important at this moment to the survival of the Latin American market. The need to understand the interculturalism of these productions, and their relation with media and local culture is visceral.

The Brazilian government also seems willing to invest in more series, if we consider recent incentives such as the FICTV/Mais Cultura initiatives. But the distribution of these productions are limited to public broadcasters, which makes their dissemination to the greater public impractical, not only in Brazil, but in Latin America too.

For now, there is space available to free-to-air channels and foreign channels active in Brazil, and within this space it seems that police themes are profiting the most. ). So, if "the question on how to create a cultural cinema and television must be understood as a quest on how to deal with interculturalism" (Garcia-Canclini, 2008), the challenge is under way. 


\section{Conclusion}

The analysis of the relationship between reality and Brazilian cinema is rich and reflects the country's history. At the onset of Brazilian cinema, crime films focusing on the felonies that occupied the main headlines were released to compete against foreign productions, which prevailed in the market. With the rise of television, cinema lost this function of commenting on reality. However, during the military dictatorship, crime films put the reality of the street back on the screen in a more down to earth language than "New Cinema", with "O Assalto ao Trem Pagador" ("Assault on the Pay Train" - 1962, Roberto Farias), "A Grande Cidade" ("The Big City" - 1966, Cacá Diegues) and "Lúcio Flávio, Passageiro da Agonia" ("Lúcio Flávio, Passenger of Agony", 1977, Hector Babenco).

In the process of the re-birth of the Brazilian Cinema, also known as the "Retake", "Central do Brasil” (Central Station, 1998, Walter Salles, Brasil-França) have been considered as a remarkable moment, when Fernanda Montenegro became the first Brazilian actress ever to be nominated for an Academy Award, but "Cidade de Deus" (City of God , 2002) represents a new era in Brazilian cinematography, followed by "Tropa de Elite 1" ("Elite Squad 1" 2007), whose sequel, in 2011, beat the record as the most viewed

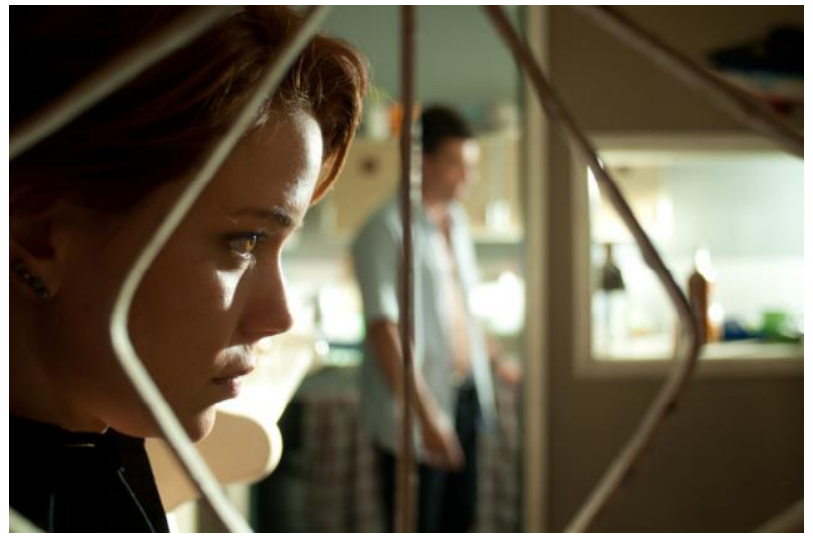
film in the history of Brazilian cinema. City of God was the first in recent year to show the real problem of drug dealers in Rio's favela, and "Elite Squad" was the first to reveal the conflicts in the corporation. These films discuss urban violence in a way 
never seen before and contribute to the narrative reflections of a crime fiction in Brazil. The next release is "O Lobo atrás da porta" (Wolf behind the Door, 2013, on the left), based on a real story about a child murdered in Rio that shocked Brasil in the 60’s.

The resurgence of audiovisual productions in Latin America during the 1990s not only affected the cinematographic sphere, but TV production as well.

Since 2000, at the turn of the millennium, new formats have emerged on broadcast television, especially cable, resulting from partnerships between major and local producers in Latin America, particularly Mexico, Argentina, Brazil, Chile and Colombia. These types of productions, led by Fox and HBO, which highlight police and action series, little by little start to challenge the place held by traditional soap operas. The purpose of this paper is to map these new media strategies (Ramonet, 2000) and understand the contribution of these productions to the constructs of local television, as a social category, and their relations with the tradition of the genre (Mitell, 2004; Naremore, 2008; Krutnik, 2010).

The latest production of HBO Latin America to explore this genre is a Chilean series, currently in its second season, called Prófugos ("Fugitives"), starring popular local actors and directed by Pablo Larraín, from the acclaimed film "Tony Manero"(2008, Brasil/Chile) and "No" (2012, Chile, USA, França, México). Prófugos shows that soap operas are definitely no longer the only Latin American fictional format, in addition to 
tapping into the global action genre tradition and marking the consolidation of a policy of intervention in the local market on the part of the major networks.

Globo will release "A Teia" (The Web), based on a real crime story, in 2014. The rival Record Entretenimento, owned by the Pentecostal church Universal do Reino de Deus, is still negotiating with Fox Films a new tv series, a cop show. As a source of inspiration, literature seems far from the Brazilian Cop Shows, closer to journalism, TV series and movies.

\section{References}

Canclini, Nestor Garcia (2008), Latin American Cinema as Industry and as Culture: its trasnational relocation. Keynote presented in Transnational Cinema in Globalising Societies Conference, Puebla, Mexico, September 29-31. 2008

Carvalho, Gilmar (2004). A Televisão no Ceará (1959-1966). Consumo, Lazer e Indústria Cultural. Fortaleza: Omni Editora.

Chandler, Daniel (1997): 'An Introduction to Genre Theory' [WWW document] URL http://www.aber.ac.uk/media/Documents/intgenre/intgenre.html [Date of Visit] Lusvarghi, Luiza Cristina, (2007). "Cidade de Deus e Cidade dos Homens.PósModernidade, exclusão social e novas tecnologias na produção audiovisual brasileira", tese de doutorado: Escola de Comunicação e Artes (ECA-USP). São Paulo: Universidade de São Paulo.

Mittell, Jason (2004), Genre and Television. From Cop Shows to Cartoons in American Culture. New York and London: Routledge.

Moya, Alvaro, Glória in Excelsior (2004). São Paulo: Imprensa Oficial do Estado.

Neale, Steve (ed.2002). Genre and contemporary Hollywood. London: BFI, 2002.

Stam, Robert (2003). Introdução à teoria do cinema. Campinas: Papirus, 2003.

Shaw, Miranda (2005). "The Brazilian Goodfellas: City of a God as a Gangster Film" in Vieira, Else. (Org.) City of God in several voices: Brazilian social cinema as action. London: CCCPress, 2005. 
FOLHA ONLINE. Coluna Outro Canal: Série só vai mostrar Rio de cartão postal. www1.folha.uol.com.br/folha/ilustrada/ult90u676289.shtm

\section{Endnotes}

'Some of Luis Fernando Veríssimo's books shift between chronicle, suspense and HQ, but cannot necessarily be classified as police stories due to the humoristic verve of the author.

ii Three films were made surrounding the events known as the "Crime da Mala" (The Suitcase Crime, see 1906): “A Mala Sinistra” (Antonio Leal); “A Mala Sinistra” or “O Crime da Mala” (producer Marc Ferrez) and "O Crime da Mala" (Alberto or Jaime Botelho). The crime occurred in 1906.

${ }^{\text {iii }}$ A Brazilian Comedy Film Genre which was very popular in the Fifties.

iv Moya considers TV Excelsior the same as TV Globo in the 1960s, in the sense of a modern conception of television with daily television news programs and telenovelas. Excelsior only lasted from 1960 to 1970 , when, unable to pay its debts, the concession was ended by the Médici government 